\title{
Děti a les: analýza mentálních map žáků čtvrtých tříd
}

\section{Jan Činčera}

Envigogika 2012/VII/1- Recenzované články/ Reviewed Papers

Publikováno/Published 31. 05. 2012

DOI: http://dx.doi.org/10.14712/18023061.67

\begin{abstract}
Abstrakt:
Článek prezentuje výzkum, který vznikl jako součást analýzy potřeb pro modifikaci programu environmentální výchovy. Zaměřuje se na kvalitativní analýzu interpretace lesa žáky čtvrtých tříd. Pro sběr dat byla využita technika mentálního mapování $(\mathrm{N}=106)$. Výzkum ukázal nekonzistence $v$ žákovských interpretacích lesa. Žáci negativně vnímají lidské působení v lese, současně ale lesu přisuzují převážně ekonomický význam. Žáci mají také malé povědomí o systémové podstatě lesa a vnímají jej spíše jako prostor vyplněný jednotlivými entitami.
\end{abstract}

\section{Klíčová slova:}

Les, mentální modely, analýza potřeb, kvalitativní výzkum

\begin{abstract}
:
The article presents a research that was conducted as a part of needs analysis for a planning modification of an environmental education program. It focuses on qualitative analysis of 4th grade pupils' interpretations. For data collection, mental mapping technique was used $(\mathrm{N}=106)$. The research showed inconsistencies in pupils' forest interpretation. Pupils negatively perceive human impact on forests but they also attribute a forest with mainly economical meaning. Pupils also do not understand a systemic nature of a forest and interpret it as a space filled by single entities.
\end{abstract}

\section{Key words:}

Forest, mental models, needs analysis, qualitative research 
Třetina plochy České republiky je pokryta lesy. Díky relativně otevřenému právnímu rámci jsou české lesy otevřené návštěvníkům, a každý má proto možnost je pravidelně navštěvovat. Co ale les pro děti znamená? Jak rozumí vzájemným vztahưm mezi lesy a lidskou společností? Principům, na kterých les jako ekosystém funguje? To byly otázky, které se vynořily jako součást analýzy potřeb předcházející úpravy programu Les ve škole, škola v lese, nabízeného školám Sdružením TEREZA.

Program Les ve škole, škola v lese je dlouhodobý program určený pro první i druhý stupeň základních škol. Sdružení TEREZA program zahájilo v roce 1999. v rámci programu jsou školám nabízeny pracovní listy vycházející z principů integrované tematické výuky (Sdružení TEREZA, 2012). Od roku 2010 začalo Sdružení TEREZA zvažovat modifikaci programu. Předkládaná studie je jedním z výstupů analýzy, která byla zpracována s cílem získat podklady pro plánování úprav programu.

Richard Louv $(2008,2009)$ popularizoval fenomén tzv. onemocnění z nedostatku kontaktu s prírodou (nature-deficit disorder). Jeho projevem je rostoucí odcizení mezi dětmi a př́rodou. Děti podle něj přestávají chodit do přírody a ztrácejí k ní vztah. To má důsledky nejenom na jejich environmentální postoje, ale i na psychický a fyzický vývoj.

Význam pobytu $v$ př́rodě byl obsahem řady studií. Podle série výzkumů tzv. významných životních zkušeností (significant life experience) je opakovaná a pozitivní zkušenost $s$ pobytem $v$ př́rodě hlavním předpokladem rozvoje tzv. environmentální senzitivity, empatie a zájmu o přírodu a životní prostředí (Palmer, 1998; Chawla, 1998, 1999; Peterson, 2005; Sward \& Marcinkowski, 2005).

Vztah mezi přímou zkušeností pobytu v přírodě, postoji vưči přírodě a jednotlivým organismům, ekologickým znalostem a proenvironmentálním chováním jsou stále předmětem zkoumání. Podle syntetizující metastudie Bogeholzové (2006) ovlivňuje postoje k přírodě a jejich odhodlanost k proenvironmentálnímu jednání nejenom četnost pobytu v př́rodě, ale i jeho interpretace. Je-li zkušenost v prrírodě vnímána utilitárně (tj. jako prostředek k dosažení jiného cíle), nemá stejný vliv na postoje a odhodlání k chování, jako hodnotí-li respondent svưj prožitek jako primárně estetický či ekologický. Podobné závěry naznačuje Vadala et al. (2007), když navrhuje rozlišovat "hru v přírodě" a "hru s př́rodou". Zatímco při "hře v přírodě" je příroda využívána utilitárně jako prostředí pro sociální interakci, ve druhém modu se stává partnerem ve hře.

Interpretace přírody je současně ovlivněna dalšími faktory. Významný vliv mají prekoncepty přírody, které děti získávají ze svého sociálního okolí a z médií. Podle Rickinsona (2001) jsou v dětských prekonceptech př́rody patrné nekonzistence. Děti přírodu vnímají současně jako přirozenou, živou entitu, která je ve své podstatě statická a existuje bez lidského vlivu. Současně vnímají přírodu jako ohroženou lidskou činností a cítí o ni starost. Děti zpravidla zastávají proenvironmentální postoje a cítí lítost, že je př́roda ničena a lesy káceny (Rickinson, 2001; Mabelis, 2005). Na druhé straně mohou děti takový postoj zastávat na obecné rovině a nemusí mít vztah ke své konkrétní krajině (Bizzeril, 2004). Vztah dětí ke zvíratům je sociálně konstruován a silně ovlivněn médii. Na obecné rovině zastávají děti přirozeně naturalistické postoje, tj. mají zájem o zvířata a jejich život. Na konkrétní rovině jsou postoje dětí ovlivněny tím, zda vnímají jednotlivé druhy jako nebezpečné a jak interpretují sociální normu týkající se žádoucí populační dynamiky druhu. Děti také vnímají pozitivněji savce, které mohou antropomorfizovat, než např́klad hmyz (Oline et al., 2003; Lukas a Ross, 2005; Heather a Wood, 2006; Fisher et al., 2011). Příroda jako celek je pro děti nejenom ohrožená, ale také ohrožující: je místem, kde na děti mưže číhat nebezpečí v podobě zlých lidí či ztracení se v terénu (Emmons, 1997; Rickinson, 2001).

Znalosti dětí o př́rodě vznikají jako výsledek dynamické souhry řady faktorů. Zatímco škola je pro žáky zdrojem vědeckých znalostí, prrímou zkušeností z prírody děti 
získávají jiný typ, tzv. tacitních vědomostí. Dalším zdrojem jsou pohádky a jiné formy antropomorfní interpretace prírody. $v$ důsledku může být přímá zkušenost pobytu z prírody okamžikem pojmové nerovnováhy a narušení původních konceptů, například v interpretaci zvířat jako milých a usměvavých kamarádů z obrazovky (Brookes, 1994; Russell, 1999).

\section{Metodika výzkumu}

Jakou mentální mapu lesa si vytváří české děti? Jak rozumí tomu, jak les funguje a jak interpretují svůj vztah k lesu? Jak chápou vztahy mezi lesem a lidskou společností? Tyto otázky stály u analýzy potřeb, zpracované v roce 2010 pro potřebu plánované modifikace programu Sdružení TEREZA Les ve škole, škola v lese.

Pro zjištění mentálních map lesa byly vytvořeny dva různé nástroje, které byly použity paralelně ve dvou skupinách respondentů: myšlenkové mapy a volný text. Následující text se zabývá analýzou dat od skupiny "myšlenkové mapy".

Myšlenkové (také pojmové či mentální) mapy patří mezi méně časté, ale používané nástroje pro sběr kvalitativních dat. Andrews, Tressler a Mintzes (2008) využili pojmové mapy pro evaluaci pobytového programu zaměřeného na mořské ekosystémy. Při zpracování pak vycházeli z kvantitativní analýzy rozdílů v komplexitě a validitě před a po programu. Podobný design byl využit ve studii Vanheara a Pace (2008) pro analýzu konceptu hmyzu u žáků prvního a druhého ročníku základní školy. Na tomto základě bylo využití myšlenkových map pro 10-11leté děti vyhodnoceno evaluačním týmem jako možné.

Žáci měli formou hesel a asociací rozvést čtyři „paprsky” myšlenkové mapy:

- Já a les: napiš všechny nápady popisující, co v lese děláš, jak souvisí s Tvým každodenním životem, co pro Tebe les znamená. Čím konkrétněji, tím lépe.

- Jak lidé les ovlivňují: sem napiš všechno o tom, jak lidé les mění, využívají, hospodaří v něm...

- Jak les funguje: čím to je, že les sám od sebe zůstane lesem a nepřemění se třeba na louku? Jaká má les vlastní „pravidla" fungování?

- Jak les ovlivňuje lidi: k čemu lidé les využívají? Jaký má les vliv na životní prostředí člověka?

Kromě těchto čtyř paprsků měli žáci k dispozici ještě pátý prázdný paprsek, do kterého mohli napsat cokoliv, co chtěli zmínit navíc.

V předvýzkumu se ukázalo, že žáci čtvrté třídy neměli s technikou myšlenkové mapy zkušenost. Pro administraci byl proto vyškolen dobrovolník, se kterým byl dvakrát simulován proces zadávání úkolu. Při zadávání byl nejprve žákům vysvětlen cíl výzkumu a dále jim byl na př́kladě pojmu "dálnice" názorně demonstrován princip myšlenkové mapy, do jejichž tvorby se zapojila celá tř́́da. Teprve poté, co skupina pochopila princip techniky, byly rozdány testy.

Ve spolupráci se Sdružením TEREZA byly vytipovány školy vhodné pro výzkum. Evaluační tým se rozhodl získat data od dvou typư škol zapojených do programu Les ve škole, škola v lese. Prvním byli žáci čtvrtých a pátých ročníků ze škol, čerstvě zapojených do programu. Kritériem bylo přihlášení do programu nejdříve na počátku školního roku 2009/10. Druhou byli žáci stejných ročníků ze škol, které realizátor považuje za pokročilé.

$\mathrm{Na}$ základě těchto kritérií dodal realizátor programu externímu evaluátorovi seznam deseti škol $v$ každé skupině. $v$ první fázi byly vybrány školy do skupiny testované pomocí myšlenkových map. Ze seznamu byly následně vyřazeny malotřídky z důvodu malého 
počtu žáků ve sledovaném věku. Ze zbylého počtu pak byly náhodným výběrem vybrány dvě školy ze skupiny pokročilých a tři ze skupiny začátečníků. Protože $v$ jedné ze škol ze skupiny "začátečníkư" byly dvě paralelní čtvrté tř́ídy, byla data sebrána v obou.

Celkem se proto podařilo získat data z šesti tříd čtvrtého ročníku. Ty jsou dále $v$ textu označovány jako třídy A, B, C, D, E a F. Celkem se podařilo získat data od 106 žáků, z toho od 51 dívek a 55 chlapců.

Tab. č. 1 Vzorek respondentů skupiny Myšlenková mapa

\begin{tabular}{|c|c|c|c|c|c|c|c|}
\hline Tříd & Dětí celkem & Dívek & Dívek \% & Chlapců & Chlapců \% & Věk \\
\hline 6 & 106 & 51 & 48,1 & 55 & 51,9 & 9,4 \\
\hline
\end{tabular}

Hlavní kategorie myšlenkových map byly předem dané a reprezentované jednotlivými „paprsky”. Ke každé hlavní kategorii myšlenkové mapy byly dále přiřazovány výpovědi žáků. Ty byly souběžně kódovány pomocí metody otevřeného kódování (Corbin \& Strauss, 2008).

Koncepty vytvořené při otevřeném kódování byly následně shrnuty pod obecnější kategorie, které se staly "subkategoriemi" hlavních kategorií. Vznikla tak mapa hlavních kategorií a jejich subkategorií:

\section{Obr. č.1 Schéma kategorií a subkategorií v myšlenkové mapě}

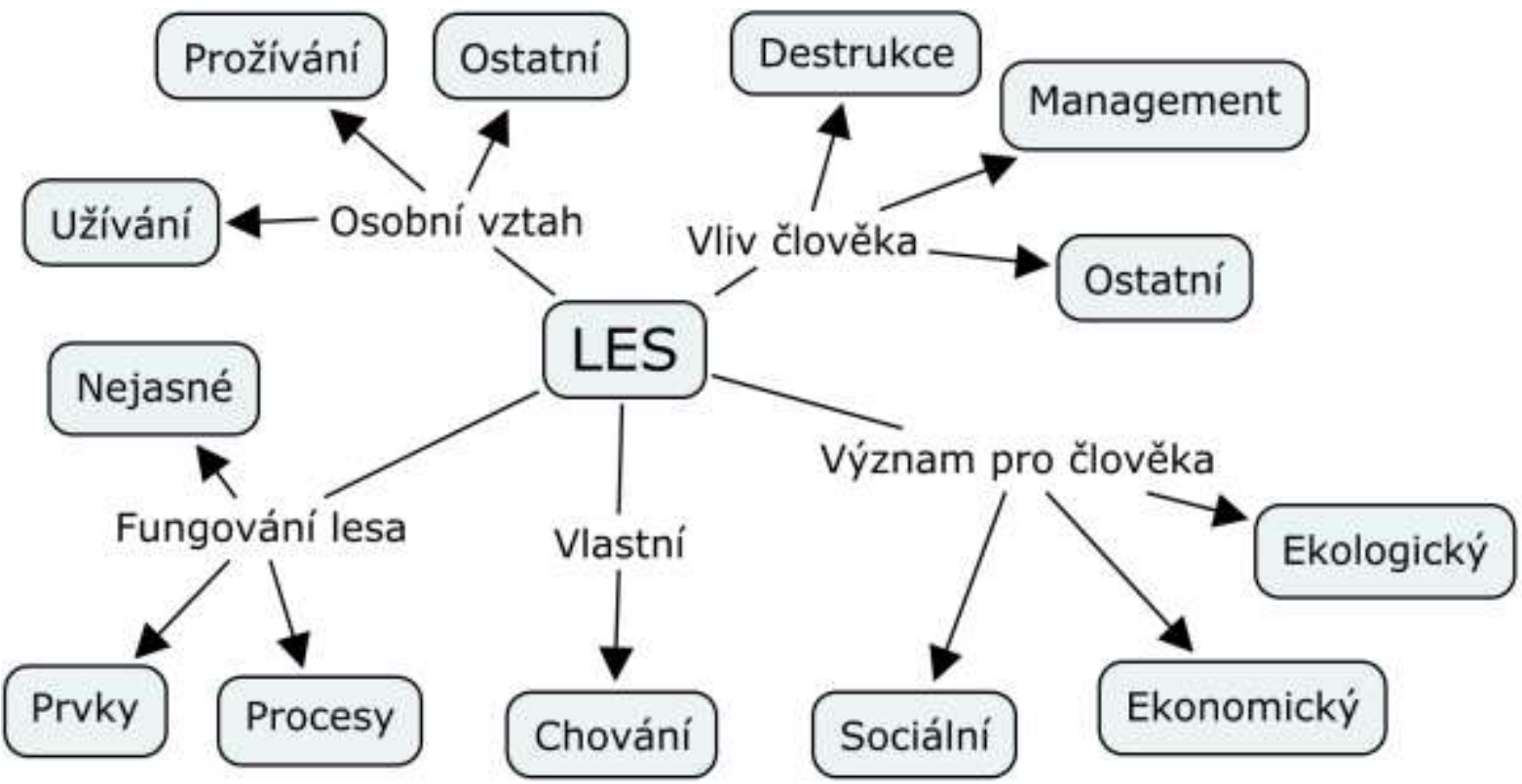

Kategorie Osobní vztah koresponduje s environmentální senzitivitou dětí. Výroky dětí byly dále děleny mezi subkategorie Prožívání, Užívání a Ostatní (Bogeholz, 2006; Thapa, 2010). Subkategorie Prožívání obsahuje výroky dětí popisující nemateriální vztah k lesu. Výroky byly kódovány koncepty: relaxace, zdraví, estetické, nespecifikované vycházky, turistika, zážitky, vztah obecně, péče o les, výzkumné zájmy, zábava. Oproti tomu subkategorie Užívání obsahovala výroky související s využiváním lesa jako zdroje materiálních hodnot. Výroky zde byly kódovány koncepty:sběr plodů, užití dřeva. 
Subkategorie Ostatní pak obsahovala výroky, které nebylo možné zařadit do předchozích dvou. Obsahovala koncepty : vize lesa, místo pro život, negativní reflexe, prostor, podmínky pro život.

Kategorie Vliv člověka byla rozdělena do subkategorií Destrukce, Management a Ostatní. Subkategorie Destrukce obsahuje výroky dětí, reflektující negativní vliv člověka na les. Subkategorie Management obsahuje výroky vyjadřující vyvážené či pozitivní působení člověka na les. Subkategorie Ostatní pak obsahuje výroky nezařaditelné do předchozích dvou.

Subkategorie Destrukce a Management nyní vyjadřují určitou dichotonomii. Subakategorie Destrukce obsahuje čistě negativní působení člověka na les a je proto vyjádřením určitého prekonceptu Lidé škodí přírodě. Subkategorie Management proto neznamená pouze převrácení negativního prekonceptu do pozitivního pólu (Lidé pomáhají prrírodě.), ale spíše posun směrem k vyváženějšímu porozumění vlivu člověka na les ( Lidé kácí, ale $i$ sázejí.). Rozdělení výroků mezi obě subkategorie tedy již lze interpretovat jako určitý kvalitativní posun v míre porozumění vlivu člověka na les.

Kategorie Fungování lesa obsahuje kromě subkategorie Nejasné opět dvě dichotomické subkategorie, Prvky a Procesy. Subkategorie Prvky obsahuje výroky dětí, které les charakterizovaly pouze pomocí jednotlivostí, a to druhů zvířat, rostlin či krajinných prvků. Subkategorie Procesy obsahuje výroky, které zachycovaly děje a interakce $v$ lese.

Kategorie Význam pro člověka je rozdělena do subkategorií Sociální, odrážející význam lesa pro sociální aktivity člověka (koncepty:relaxace, zdraví, místo, estetická funkce, objekt vztahu, turistika), Ekonomický, vyjadřující význam pro ekonomické činnosti (koncepty: potrava, zemědělské využití, zdroj surovin, prưmyslové využití, zaměstnání) a Ekologický, vyjadřující význam pro fungování ekosystému, jehož je člověk součástí. Nezařaditelné výroky (koncepty: překážka, nebezpečí) byly kódovány jako Ostatní.

Nejčastěji se vyskytujícími komentáři u prázdného paprsku byly výroky související se správným či nesprávným chováním v lese. Ostatní výroky byly zařaditelné do některé z ostatních kategorií.

\section{Výsledky}

Popis skupin

\section{Skupina a (malá obec, $\mathbf{N}=30$ )}

Děti chodí do lesa nejčastěji sbírat houby, ale také borůvky, jahody, maliny, ostružiny. Dál se do lesa chodí "odreagovat od učení", odpočinout si, přemýšlet či uklidňovat. Dvě děti vnímají význam čerstvého vzduchu na zdraví: „jsme zdraví a silní". Další si uvědomují estetickou hodnotu lesa: „v lese jsou krásné stromy - stromy jsou vysoké". Do lesa chodí na procházky či bydlí v jeho blízkosti. Výroky vyjadřují pozitivní vztah k lesu: "jsem ráda, že je blízko". s lesem spojují dobrodružství i zážitky: stejný počet dětí (15), jaký uvedl sběr lesních plodů, uvádí také, že si v lese hraje: staví bunkry či domečky: "v lese si hraju a stavím domečky pro zvěř". Další les zkoumají a pozorují, př́padně o něj pečují: „v zimě jdu s tetou pověsit na stromeček něco zvířátkưm”, „čistím ho - od skla a napadaného dřeva"; „v lese žijí zvířata - dáváme jim v zimě jídlo - staráme se o ně". v menším počtu se objevují výroky popisující dětské či rodinné ničení lesa: "krademe stromečky", "kácíme stromy na topení".

Celkově Ize shrnout, že ve výrocích v naprosté většině převažuje pozitivní vnímání lesa jako místa spojeného s př́jemnými zážitky, legrací, něčím zajímavým či užitečným. 
Vliv člověka chápe zhruba stejně velký počet dětí jako destruktivní a jako manažerský. Děti uvádějí, že lidé „parkují v chráněné oblasti - hází tam odpadky a sklo", "ničí - kácí stromy na dřevo", kácejí stromy na Vánoce, či souhrnně "ubližují lidé moc lesu". Do lesa vyhazují odpadky, les pálí, dělají hluk - „zvířátka se boji", "dávají tam rưzné nečistoty, znečištují les, potůčky". Celkově tedy lze říct, že děti reflektují poškozování lesa především jako kácení stromů či vyhazování odpadků, v menší míre jako poškozování ohněm či hlukem.

Na druhé straně děti uvádějí, že se lidé starají o zvířata: „dávají zvířatům jídlo, na zimu dávají jídlo do krmelce" a že kácení kompenzují sadbou: "sázejí tam nové sazenice kácejí je, aby mohli topit". Znečištění lesa odpadky pak lidé řeší jejich sběrem: „pečují o něj - sbíráme odpadky - sklínky od piva, vína, či kompotu". Osobami, které se starají o les, jsme jak my všichni („sbíráme odpadky"), tak lesníci a myslivci.

Dvě třetiny dětí charakterizovaly fungování lesa výčtem prvků - živočichů, rostlin či krajinných. v odpovědích se objevilo široké zastoupení různých konkrétních prvkư (stromy, keře, rostliny, houby, zvírata, hmyz, pohádkové bytosti, ptáci, stopy zvírat). Přírodní procesy, které se objevily, je možné rozdělit do čtyř typů: produkce kyslíku, potravinové řetězce ("živočichové jí rostliny"), regenerace ("funguje tak, že v něm vyrůstají nové a nové stromy") a symbióza ("některé houby rostou na stromech"). Nejčastěji uváděnými příklady byly produkce kyslíku a potravinové řetězce.

Ekologická rovina významu lesa pro člověka pro děti v naprosté většině př́padů souvisí s produkcí kyslíku („je z něho kyslík a lepší vzduch - díky němu můžeme dýchat"). v jednom případě žák uvádí vliv lesa na zadržování vlhkosti ("není mokro"). Další připomínají čistotu vzduchu.

Čistota vzduchu souvisí s vlivem lesa na zdraví. Les podle dětí „nám pomáhá se zdravím", "lidé tam chodí pro život", "někdy pomáhá lidem s nějakým problémem". z dalších sociálních funkcí děti uvádí turistiku či relaxaci spojenou s tichem.

Jako ekonomické využití pak byly kódovány sběr plodů v lese, využití stromů na dřevo pro topení či výrobu nábytku („Iidé řezají stromy na dřevo - lavice a skříň - práce") či využití trusu zvířat jako hnojiva.

V lese se podle dětí ",nekouří", "nehoní se zvěř, nekřičí se tam”, nesmí se tam "házet odpadky", kopat do hřibů, schválně ho ničit, pohazovat ostré věci, řezat stromy, zabíjet srny či stř́let po „ptácích". Naopak je správné "sázet a starat se o malé stromky” či chovat se potichu.

\section{Skupina B (krajské město, $\mathbf{N}=11$ )}

Stejný počet dětí uvedl příklady osobního vztahu k lesu v subkategorii užívání i prožívání. Děti v lese sbírají houby (4), jezdí tam na kole, venčí psa nebo chodí na vycházky samy či s družinou. Pro tři děti je les prostor, kterým prochází po cestě domů či na chatu. Pouze jedno dítě uvedlo, že si v lese hraje nebo jej zkoumá („poznávám v něm nové věci"). Dvě děti uvedly, že do lesa moc nechodí. Ve srovnání se skupinou a je zde mnohem menší počet výroků i různých aktivit (což je samozřejmě dáno i třetinovým počtem respondentů), celkové vyznění je méně pozitivní a spíše asociuje les jako pragmatickou realitu, kterou děti využívají či akceptují, ale většinou ji nechápou jako místo vybízející ke hře. To je patrné i proporčně: ve skupině a charakterizovalo les jako místo ke hře 15 dětí, tj. polovina. Ve skupině $B$ je to pouze jediné dítě.

Destrukce lesa souvisí s jeho kácením („lidé uříznou stromy malé a pak je přemístí a pak je prodaji“"). Management s nahrazováním těžby výsadbou ("lidé uříznou třeba 5 stromů a pak nechají narưst nové stromy"), jednotlivci uvedli také likvidaci škůdců a úklid. 
Z konkrétních prvků uváděných jako odpověd' na fungování lesa žáci uvedli ježka, veverku a prrírodní památky, jinak uváděli obecnější kategorie (stromy, keře, houby). Uvedeny byly dva ekologické principy: potravinové řetězce a příslušnost druhů k určitému habitatu („les produkuje pro zvířata jídlo, prostředí, domov - jsou tam štastná").

Význam lesa je pro žáky z této skupiny spojen nejvíce s ekonomickými činnostmi, resp. těžbou dřeva na "teplo, nábytek, papír". Na dalších místech je využití pro jídlo (maso, houby), relaxaci (klid, ticho) a ekologická funkce ("tvoří lidem vzduch"). v lese se nemá křičet.

\section{Skupina C (bývalé okresní město, $\mathrm{N}=14$ )}

Ve skupině výrazně převyšuje užívání nad prožíváním: zejména díky sběru plodů, který zmínilo 11 ze 14 dětí. Žádné neuvedlo les jako místo pro hru. Dvě děti uvedly rưzné príklady zkoumání lesa („koukám se na zvířata, naveverky jak jedí šišky"), tři děti chodí do lesa na vycházky ("chodíme tábořit, stanovat"), jedno uvedlo, že má rádo vůni lesa. Ve skupině se ale objevilo i několik negativních reflexí lesa, vyjadřujících strach či ohrožení. Jedno dítě spojilo sbírání hub s rizikem otravy ("sbírám houby - někdy i jedovaté - lidé umírají v lese"), další spojuje les s pavouky, kterých se bojí („já do lesa ráda nechodím, protože se hrozně bojím pavoukư a tam jich je hodně"). Třetí dítě uvádí jako zdroj ohrožení klíštata („potom nás ale mami zkontroluje, protože v lese žije klíště”).

V popisu vlivu člověka na les velmi výrazně převažují výroky odpovídající destruktivnímu pólu. Lidé poškozují les těžbou a kácením, znečišt́ují jej odpadky („existují dva druhy lidí - poslušní a neposlušní - první skupina si lesů moc váží, ale ta druhá má les za skládku - hází tam bordel"), ohněm, nelegálním lovem zvířat, vizuálním znečištěním („dávají k nim billboardy") a hlukem („když někdo zařve, zvířata se bojí").

Výroky popisující manažerskou roli člověka byly v menšině. Podle nich lidé udržují rovnováhu mezi těžbou a sázením ("kácejí ho - aby ho mohli vysazovat, vysazují ho, aby ho mohli kácet", "stavějí a kácejí stromy, rozbíjí je a opravují je"), případně les „čistí" či "chrání zvířata". Podle jednoho hodnocení "lidé s ním velmi špatně hospodaří, protože pořád kácí, místo aby třídili". Jedno z dětí zmiňuje vliv člověka na rozmnožování rostlin: "když lidé chtějí, aby jim něco vyrostlo, tak jdou na zahradu, dají tam semínko, zafouká vítr a semínka se rozfoukají do lesa".

K fungování lesa se děti vyjadřovaly nejméně ze všech kategorií, poměr dětí uvádějících prvky/procesy byl zhruba v rovnováze. v lese jsou podle dětí zvířata, stromy, lesy "listnaté a smíšené", z konkrétních druhư jedno dítě zmiňuje "prase, jelen, srna a hadi".

V procesech děti zmiňují potravinové vztahy, růst, rozmnožování a materiálové toky ("recykluje odpadky a není v něm nepořádek", "jsou tam zvírata - rozmnožují se a hubí se", "když strom vyroste tak už zpátky nepoleze").

Význam pro člověka vidí nejvíce dětí v ekonomickém využití, naopak ekologickou funkci (kyslík) uvedlo jen minimum dětí. Les je pro děti především zdrojem hub a dřeva, které se používá na topení, stavby, papír, hračky, stromy se kácejí i kvůli Vánocưm („kácejí ho, aby měli dřevo na oheň, na stavbu a aby měli papír"). Podle jednoho dítěte mají les rádi: „lesní svěř, lesníci a hipísáci”.

\section{Skupina D (vesnice, $\mathbf{N}=16)$}

O něco více dětí charakterizovalo svůj vztah k lesu jako prožívání, než užívání. Většina dětí sbírá lesní plody, téměř stejný počet ale chodí do lesa relaxovat („poslouchám les a lehnu si na trávu, zpívám si a jsem"), další vnímají estetickou hodnotu lesa („sbíráme si tam nějaké ozdoby na výrobky z přírodního materiálu"), polovina děti chodí do lesa na procházky, další si v lese hrají („hrajeme hry, stavím si bunkry, lezu po stromech, lezu po kmenech přes vodu"), dívají se na zvířata nebo si uvědomí význam lesa pro své zdraví. 
Celkově Ize říct, že děti reflektují les pozitivně a podle svých výpovědí jsou s ním často $\mathrm{v}$ interakci.

Vliv člověka je převážně vnímán negativně. Lidé podle dětí „zabíjí zviř̌ata, ničí les, zapalují ho, kácí stromy", dělají hluk a znečištúuji les odpady. Lidé také les upravují způsobem, který jej neničí: „jsou tam značky pro turisty - aby trefili domư". Péče o les byla zmiňována jen málo, podle ní lidé sází stromy a staví krmítka.

Pouze jedno dítě vysvětlilo fungování lesa popisem procesů, tři čtvrtiny dětí ale uvedly príklady různých prvků. Těmi ale většinou byly obecnější kategorie, jako stromy, zvírata, houby.

Les je pro děti významný především pro zajištění sociálních aktivit, ekologickou funkci uvedl jen jeden žák. Les lidé využívají jako zdroj potravy („hodně keřů - ovoce a jogurty, hodně zvírat - maso") a jako zdroj surovin ("hodně stromů - dřevo - pomáhá jim topit").

\section{Skupina E (menší město, $\mathbf{N}=19$ )}

Rozložení odpovědí na osobní vztah k lesu mezi užívání a prožívání je téměř identické, jako u skupiny A. Většina dětí sbírá houby a další plody, třetina dětí uvádí, že do lesa chodí na procházky, se psem či na koni, v lese si hraje: staví domečky, hraje si na přišery nebo "hraju si tam s klacky, co spadly". Jedno dítě baví pozorovat přírodu: "baví mě dívat se na ptáky a stromy", dvě děti o les pečují "dáváme potravu zviŕatưm". Poměrně velká část dětí (třetina) vyjadřuje pozitivní vztah k lesu: „je hezky veliký - je hezký", „krásný les", "moc se mi líbí".

Zhruba dvakrát více dětí vnímá vliv člověka spíše jako destruktivní, než manažerský. Lidé kácí stromy, zabíjí zviřata a znečištují les odpady ("dělají z něj mýtiny - řežou", "kácejí je pytláci, zabíjejí zvířata"). o les pečují myslivci, chování lidí v lese je regulováno pravidly, jako je "zákaz ohně". o les se lidé dále starají tak, že sázejí stromy a přikrmují zviŕata - „v zimě dávají do krmítka kaštany a sưl".

Jen dvě děti charakterizovaly fungování lesa popisem procesů (kyslík, prostředí pro rozmnožování), oproti deseti, které uváděly příklady různých prvků. Těmi jsou vesměs obecné kategorie (stromy, houby, zviŕata), jeden respondent uvedl pět různých stromů: "bříza, smrk, buk, dub, borovice".

Nejvíce dětí charakterizovalo význam lesa pro člověka na ekonomické rovině. Les je zdrojem dřeva, ze kterého se vyrábí hračky, nábytek a papír, les je také zdrojem hub. Dvě děti uvedly, že les dává lidem kyslík. Dvě děti uvedly, že lidé chodí do lesa rádi na procházku, protože mají rádi zvírata a les je krásný, že je les zdravý, protože je v něm "hodně zdravého kyslíku uhličitého" a že v něm lidé relaxují, protože je v něm ticho („je tam ticho - je tam ozvěna").

\section{Skupina F (paralelní třída k E, N=16)}

O něco více dětí charakterizuje svůj vztah k lesu jako užívání, než jako prožívání. Většina dětí sbírá houby, jedno uvedlo, že sbírá listí. Šest dětí uvedlo, že mají les rády a líbí se jim tam („les je krásný - líbí se mi jehličnaté stromy", "les mi voní). Několik uvádí, že do lesa chodí na procházku („já a můj pes v lese - chodím s ním na procházky hraju si s ním a oba si to užíváme", "je tam príroda a já mám ráda prírodu, pes v lese chodím s ním na procházku - vždycky nám uteče"). Dvě děti uvedly, že se starají o les (krmí zvírata či sbírají odpadky), jedno si v lese hraje hry.

Srovnatelný počet dětí vnímá vliv člověka na les jako destruktivní či jako manažerský. Lidé les poškozují kácením, pálením, hlukem a odpadem („zlí lidé ho kácí, chodí tam na lov", "ničí ho odpadem - les umírá"). o les pečují myslivci, kteří ho "hlídají, 
aby byl v pořádku", "starají se o zvířata", "bydlí v něm myslivci - míchá les s listnatými stromy i s jehličnatými stromy". Všechny lesy jsou podle jednoho žáka chráněny, "lidé staré stromy vykácejí, aby měli místo pro nové stromy".

Deset dětí ku čtyřem vysvětluje funkce lesa popisem prvků oproti vysvětlení procesů. Děti zmínily dva procesy: rozmnožování („zvířata - roznášejí šišky a tak dále, ze kterých vyroste strom") a produkci kyslíku. z prvkủ žáci uvedli ovocné keře a ovocné stromy (borůvky, lesní jahody, maliny, ostružiny, jabloň, hrušky).

Největší část dětí vnímá význam lesa pro člověka prostřednictvím jeho ekologické funkce. Tou je produkce kyslíku, jedno dítě uvedlo, že "kdyby nebyly rostliny, nebyli by lidé". o málo menší počet dětí zmiňuje ekonomický význam lesa, jako je zdroj hub a dřeva, které se používá pro topení a výrobu nábytku. Několik dětí uvedlo, že les je místem pro relaxaci, protože v lese je ticho a zdravý vzduch („nadýcháme se tam kyslíku a když jsme potichu, tak tam uvidíme zvíře").

Šest děti zmínilo, co se v lese smí či nesmí: „nesmí křičet, nesmí odhazovat odpadky, stromy - nemáme do nich kopat a trhat větve, nezahazují se tam odpadky ani láhve".

\section{Porovnání skupin}

Tab. č. 2 Relativní četnost výskytu významových jednotek $v$ rámci jednotlivých subkategoriích (\%):

\begin{tabular}{|c|c|c|c|c|c|c|c|c|}
\hline & & & $A=30$ & $B=11$ & $C=14$ & $D=16$ & $E=19$ & $F=16$ \\
\hline \multicolumn{9}{|l|}{$\begin{array}{l}\text { osobní } \\
\text { vztah }\end{array}$} \\
\hline & Prožívání & $\begin{array}{c}\text { relaxace, zdraví, } \\
\text { estetické, } \\
\text { nespecifikované } \\
\text { vycházky, turistika, } \\
\text { zážitky, obecně vztah, } \\
\text { péče o les, výzkum, } \\
\text { zábava }\end{array}$ & 73 & 45 & 57 & 88 & 74 & 50 \\
\hline & Užívání & sběr plodů, užití dřeva, & 53 & 45 & 79 & 75 & 58 & 75 \\
\hline & Ostatní & $\begin{array}{l}\text { vize lesa, místo pro } \\
\text { život, negativní, } \\
\text { prostor, podmínky pro } \\
\text { život }\end{array}$ & 13 & 19 & 21 & 6 & 0 & 13 \\
\hline \multicolumn{9}{|l|}{$\begin{array}{l}\text { vliv } \\
\text { člověka }\end{array}$} \\
\hline & Destrukce & ničení, znečištění & 57 & 64 & 79 & 69 & 58 & 56 \\
\hline & Management & management lesa & 53 & 18 & 21 & 25 & 32 & 44 \\
\hline & Ostatní & místo pro život, nejasné & 3 & 0 & 21 & 0 & 0 & 19 \\
\hline Eungování & & & & & & & & \\
\hline
\end{tabular}




\begin{tabular}{|c|c|c|c|c|c|c|c|c|}
\hline \multicolumn{9}{|l|}{ lesa } \\
\hline & Prvky & & 73 & 55 & 36 & 75 & 53 & 63 \\
\hline & Procesy & & 23 & 19 & 29 & 6 & 11 & 25 \\
\hline & Nejasné & & 3 & 19 & 0 & 13 & 0 & 0 \\
\hline \multicolumn{9}{|c|}{ význam pro člověka } \\
\hline & Environmentální & ekologická funkce & 47 & 27 & 14 & 6 & 21 & 56 \\
\hline & Ekonomická & $\begin{array}{l}\text { potrava, zemědělské } \\
\text { využití, zdroj surovin, } \\
\text { průmyslové využití, } \\
\text { ekonomické obecně }\end{array}$ & 63 & 64 & 57 & 31 & 47 & 43 \\
\hline & Sociální & $\begin{array}{c}\text { relaxace, zdraví, místo, } \\
\text { estetická funkce, objekt } \\
\text { vztahu, turistika }\end{array}$ & 47 & 36 & 36 & 63 & 32 & 38 \\
\hline & Ostatní & překážka, nebezpečí & 0 & 18 & 14 & 0 & 0 & 6 \\
\hline & & & 0 & 0 & 0 & 0 & 0 & 0 \\
\hline $\begin{array}{l}\text { Chování } \\
\text { v lese }\end{array}$ & \multicolumn{2}{|c|}{ co se v lese nemá/ má } & 20 & 9 & & 36 & & 6 \\
\hline
\end{tabular}

Ze srovnání jsou dále patrné některé vzorce. Je zřejmé, že většina dětí chápe vliv člověka na les jako destruktivní. Současně uvádí vždy př́mou destrukci, ke které dochází z důvodu nesprávného chování (proti pravidlům) nebo z důvodu ekonomického využívání lesa.

Téměř pro všechny skupiny platí, že hlavní význam lesa pro člověka vidí v jeho ekonomické využitelnosti jako zdroje plodů a dřeva.

Všechny děti mají také problémy vysvětlit fungování lesa pomocí popisu procesů, které v lese probíhají. Mnohem častěji proto vysvětlují les jako množinu prvků, které se $v$ něm nacházejí.

Vzhledem k malému počtu skupin je možné diskutovat pouze o dílčích podobnostech. Zdá se, že myšlenkové mapy odrážející kvalitativně nejvyšší míru vhledu do lesní problematiky a současně pozitivní osobní vztah k lesu mají skupiny a a D. Další podobnosti najdeme ve dvojicích B a F či C a E.

\section{Diskuse}

Vztah dětí $\mathrm{k}$ lesu je plný paradoxů. Na jedné straně jsou děti v lese rády a negativně vnímají jeho poškozování a kácení stromů. Děti vnímají roli člověka $v$ převážně destruktivní rovině, jako někoho, kdo svým neukázněným chováním nebo bezohledným 
využíváním les poškozuje. Méně často si uvědomují roli člověka jako správce lesa. Kácení téměř vždy vnímají negativně a neuvědomují si jeho důvody související s péčí o les. Na druhé straně nejčastěji přisuzují lesu ekonomický význam, zejména jako zdroje dřeva a dalších surovin.

Můžeme předpokládat, že tato nekonzistence je způsobena střetem mezi různými zdroji znalostí o lese. Jedním jsou pravděpodobně obecné proenvironmentální postoje vytvářené médii i dalšími vlivy, ve kterých je člověk zpravidla interpretován jako zdroj environmentálních problémů (Rickinson, 2001). Je možné, že jiným zdrojem může být formální výuka, ve které se žáci učí uvažovat o přírodě jako o zdroji surovin pro uspokojení lidských potřeb. Taková teorie by ale musela být ověřena v dalším výzkumu.

Děti na otázku „jak funguje les" uváděly zpravidla výčty prvků, namísto procesů a vztahů. To může naznačovat, že děti nechápou les jako živý systém, ale jako prostor vyplněný různými entitami. Pokud by se taková teorie potvrdila i v dalších výzkumech, znamenala by taková skutečnost závažné imperativy pro výuku př́rodních věd a pro environmentální výchovu. Pokud si žáci neosvojí základní koncepty fungování přírody, jako je například koncept cyklů, potravního řetězce, vzájemné provázanosti či další, budou jen velmi obtížně rozumět potřebám př́rody a tomu, jak s nimi sami souvisí. Přestože porozumění těmto základním ekologickým principům nepatří mezi faktory, které ovlivňují ochotu brát ve svém rozhodování v potaz zájem životního prostředí, předpokládá se, že ovlivňuje kvalitu takového rozhodnutí (Hungerford a Volk, 1990).

Problémy, které čeští žáci mají v oblasti přírodovědné inteligence, dokládá i studie PISA. Podle ní mají čeští žáci nadprưměrné znalosti biologie, ale ve schopnosti aplikovat tyto znalosti do reálného světa zůstávají pod průměrem (Palečková, 2007). v širším kontextu jsou ale problémy v nepropojování si znalostí o ekologických principech a vlastním chováním doloženy i z jiných zemí (Boschhulzen a Brinkman, 1995).

Výzkum, který vznikl jako součást analýzy potřeb pro středisko ekologické výchovy, je príspěvkem do diskuse, kterou zatím reprezentuje několik původních prací českých autorů (Strejčková, 2006; Franěk, 2007; Jančaříková, 2009; Krajhanzl, 2010). Interpretace prrírody dětmi představuje velké výzkumné téma, které přináší řadu otázek. Nalezení odpovědí je pak klíčové pro správné nastavení školních i mimoškolních programů environmentální výchovy.

\section{Seznam použité literatury}

- Andrews, K. E., Tressler, K. D., \& Mintzes, J. J. (2008). Assessing environmental understanding: an application of the concept mapping strategy.Environmental Education Research, 14(5), 519-536. Retrieved from http://www.tandfonline.com/doi/abs/10.1080/13504620802278829 http://dx.doi.org/10.1080/13504620802278829

- Bizerril, M. X. A. (2004). Children's Perceptions of Brazilian Cerrado Landscapes and Biodiversity. The Journal of Environmental Education, 35(4), 47-58. Retrieved from http://www.tandfonline.com/doi/abs/10.3200/JOEE.35.4.47-58 http://dx.doi.org/10.3200/JOEE.35.4.47-58

- Boschhuizen, R., \& Brinkman, F. G. (1995). The Concept of Cycles for Environmental Education. Environmental Education Research, 1(2), 147-158. Retrieved from http://www.tandfonline.com/doi/abs/10.1080/1350462950010202 http://dx.doi.org/10.1080/1350462950010202

- Bögeholz, S. (2006). Nature experience and its importance for environmental knowledge, values and action: recent German empirical contributions.Environmental Education Research, 12(1), 65-84. Retrieved from http://www.tandfonline.com/doi/abs/10.1080/13504620500526529 http://dx.doi.org/10.1080/13504620500526529 
- Brookes, A. (1994). Reading between the Lines-Outdoor Experience as Environmental Text. Journal of Physical Education, Recreation \& Dance, 65(8), 28-39. Retrieved from http://www.tandfonline.com/doi/abs/10.1080/07303084.1994.10606979 http://dx.doi.org/10.1080/07303084.1994.10606979

- Corbin, J., \& Strauss, A. (2008). Basics of Qualitative Research. 3e. Techniques and Procedures for Developing Grounded Theory. Thousand Oaks: Sage.

- Emmons, K. M. (1997). Perceptions of the Environment while Exploring the Outdoors: a case study in Belize. Environmental Education Research, 3(3), 327-344. Retrieved from http://www.tandfonline.com/doi/abs/10.1080/1350462970030306 http://dx.doi.org/10.1080/1350462970030306

- Fischer, A., Langers, F., Bednar-Friedl, B., Geamana, N., \& Skogen, K. (2011). Mental representations of animal and plant species in their social contexts: Results from a survey across Europe. Journal of Environmental Psychology, 31(2), 118-128. Retrieved from http://linkinghub.elsevier.com/retrieve/pii/S0272494410000563 http://dx.doi.org/10.1016/j.jenvp.2010.05.005

- Franěk, M. (2007). Představy českých respondentů o postavení člověka v prírodě. Československá psychologie, 2, 161-168.

- Looy, H., \& Wood, J. R. (2006). Attitudes towards Invertebrates: are Educational ,Bug Banquets' Effective? 2006. The Journal of Environmental Education,37(2), 37-49. Retrieved from http://www.tandfonline.com/doi/abs/10.3200/JOEE.37.2.37-48 http://dx.doi.org/10.3200/JOEE.37.2.37-48

- Louise, C. (1999). Life Paths Into Effective Environmental Education. The Journal of Environmental Education. Vol. 31, no. 1, p. 15-26. ISSN 0095-8964.The Journal of Environmental Education, 31(1), 15-26.

- Chawla, L. (1998). Significant Life Experiences Revisited: A Review of Research on Sources of Environmental Sensitivity. The Journal of Environmental Education, 29(3), 11-21. Retrieved from $\quad$ http://www.tandfonline.com/doi/abs/10.1080/00958969809599114 http://dx.doi.org/10.1080/00958969809599114

- Jančaříková, K. (2009) Výsledky empirického výzkumu dětských kontaktů s přírodou. In Člověk+príroda=udržitelnost. Texty o proměně vztahu lidí $k$ prírodě, environmentální výchově a udržitelnosti (pp. 16-27). Praha: Zelený kruh.

- Krajhanzl, J. (2010). Charakteristika osobního vztahu k prírodě. Úvod do teorie a pojmosloví. [Disertační práce]. Praha: Univerzita Karlova.

- $\quad$ Richard, L. O. U. V. (2008) Last Child in the Woods: Saving Our Children From Nature-Deficit Disorder. In Last Child in the Woods: Saving Our Children From Nature-Deficit Disorder. Chapel Hill, N.C: Algonquin Books.

- Louv, R. (2009) Do Our Kids Nature-Deficit Disorder?. In Educational Leadership (pp. 24-32).

- $\quad$ Lukas, K. E., \& Ross, S. R. (2005). ZOO Visitors Knowledge and Attitudes towards Gorillas and Chimpanzes. The Journal of Environmental Education, 36(4), 33-49.

- Mabelis, A. S. (2005). Children's Opinions about the Loss of Nature. Southern African Journal of Environmental Education, 22, 123-137.

- MYERS, O.E. Jr.,, Saunders, C. D., \& Garrett, E. (2004). What do children think animals need? Developmental trends. Environmental Education Research, 10(4), 545-562. Retrieved from $\quad$ http://www.tandfonline.com/doi/abs/10.1080/1350462042000291056 http://dx.doi.org/10.1080/1350462042000291056

- Oline, E., MYERS, O.E. Jr., , Saunders, C. D., \& Garrett, E. (2003). What Do Children Think Animals Need? Aesthetic and Psycho-social Conceptions.Environmental Education Research, 9(3), 305-325. Retrieved from 
http://www.tandfonline.com/doi/abs/10.1080/13504620303461 http://dx.doi.org/10.1080/13504620303461

- Palmer, J. A., Suggate, J., Bajd, B., K.P., Paul Hart, , Ho, R. K. P., Ofwono-Orecho, J. K. W., ... Staden, C. V. (1998). An Overview of Significant Influences and Formative Experiences on the Development of Adults' Environmental Awareness in Nine Countries. Environmental Education Research, 4(4), 445-464. Retrieved http://www.tandfonline.com/doi/abs/10.1080/1350462980040408 http://dx.doi.org/10.1080/1350462980040408

- Palečková, (Jana) et al., (2007). Hlavní zjištění výzkumu PISA 2006. Poradí si žáci s prírodními vědami?. Praha: Ústav pro informace ve vzdělávání.

- Peterson, N. (2005) Factors Influencing the Development of Environmental Sensitivity. In H. H. Hungerford, W. J. Bluhm, T. L. Volk, \& J. M. Ramsey (Eds.), Essential Readings in Environmental Education (pp. 295-300). Champaign: Stipes.

- Rickinson, M. (2001). Learners and Learning in Environmental Education: A critical review of the evidence. Environmental Education Research, 7(3), 207-320. Retrieved from http://www.tandfonline.com/doi/abs/10.1080/13504620120065230 http://dx.doi.org/10.1080/13504620120065230

- Russell, C. (1999). Problematizing nature experience in environmental education: The interrelationship of experience and story. The Journal of Environmental Education, 22(3), 123-127.

- Tereza, S. (2012). Les ve škole, škola v lese. . Retrieved from http://lesveskole.terezanet.cz/

- Strejčková, E. (2006). Výzkum odcizování člověka prírodě. Závěrečná zpráva. Praha: Toulcův dvůr. Retrieved from http://www.detiamesto.cz

- Sward, L. L., \& Marcinkowski, T. (2005) Environmental Sensitivity: A Review of the Research, 1980-1998. In H. H. Hungerford, W. J. Bluhm, T. L. Volk, \& J. M. Ramsey (Eds.), Essential Readings in Environmental Education (pp. 301-312). Champaign: Stipes.

- Thapa, B. (2010). The Mediation Effect of Outdoor Recreation Participation on Environmental Attitude-Behavior Correspondence. The Journal of Environmental Education, 41(3), 133-150. Retrieved from http://www.tandfonline.com/doi/abs/10.1080/00958960903439989 http://dx.doi.org/10.1080/00958960903439989

- VADALA Carin E, , BIXLER Robert D, , \& JAMES J Joy 2007, (2007). Childhood Play and Environmental Interest: Panacea of Snake Oil. The Journal of Environmental Education, 39(1), 3-18. Retrieved from http://www.tandfonline.com/doi/abs/10.3200/JOEE.39.1.3-18 http://dx.doi.org/10.3200/JOEE.39.1.3-18

- Vanhear, J., \& Pace, P. J. (2008). Integrating knowledge, feelings and action: Using Vee heuristics and concept mapping in education for sustainable development. Journal of Teacher Education for Sustainability, 10, 43-55.

PhDr. Jan Činčera, Ph.D.

Autor vyučuje environmentální výchovu a prožitkovou pedagogiku na Technické univerzitě v Liberci. Jako evaluátor programů dále spolupracuje se středisky ekologické výchovy a organizacemi zabývajícími se globálním rozvojovým vzděláváním.

profesní zaměření: environmentální výchova, vzdělávání pro udržitelný rozvoj, výchova o Zemi, evaluace programů, pedagogika volného času, informační věda 


\section{Email: jan.cincera@tul.cz}


Časopis Envigogika vydává Centrum pro otázky životního prostředí UK. Vývoj časopisu je podpořen projektem OP VK Mezioborová sít udržitelného rozvoje.

Více najdete na internetových stránkách projektu http://mosur.czp.cuni.cz
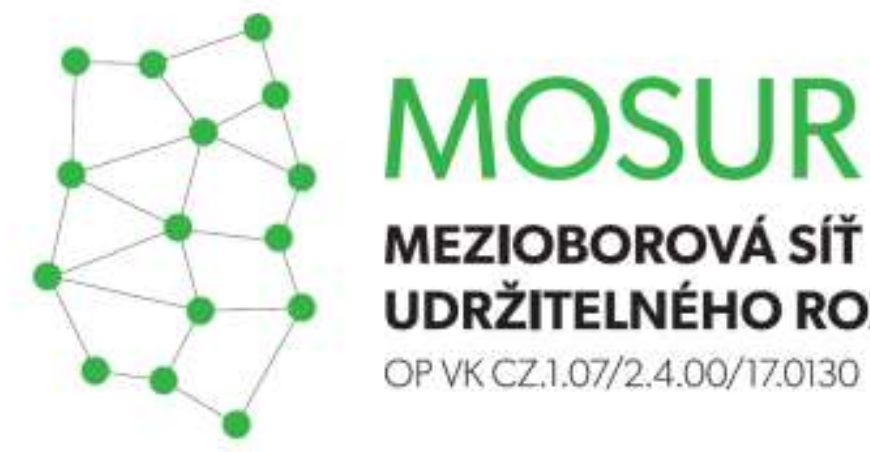

\section{MEZIOBOROVÁ SÍT}

UDRŽITELNÉHO ROZVOJE

OP VK CZ.1.07/2.4.00/17.0130
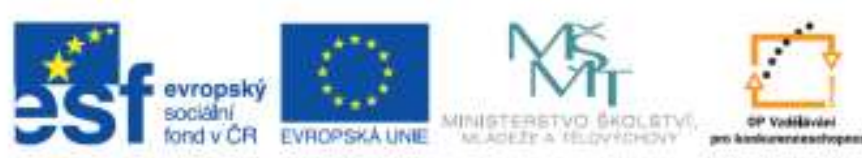

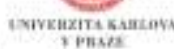

INVESTICE DO ROZVOJE VZDELAVANI 